\title{
Diabetes mellitus: in search of an improved classification and treatment algorithm
}

\section{Diabetul zaharat: în căutarea unei clasificări şi a unui algoritm terapeutic îmbunătăţit}

\author{
Simona Cernea ${ }^{1,2^{*}}$, Avivit Cahn ${ }^{3}$ \\ 1. Division of Internal Medicine IV, Department M3, University of Medicine and Pharmacy, \\ Târgu Mureş, Romania; 2. Diabetes, Nutrition and Metabolic Diseases, Emergency County Clinical \\ Hospital, Târgu Mureş, Romania; 3. Diabetes Unit, Department of Internal Medicine, Hadassah \\ Hebrew University Hospital, Jerusalem, Israel
}

\begin{abstract}
Our current clinical doctrine and practice is based upon a classification of diabetes which relies mainly on some clinical manifestations/criteria, rather than markers of the pathophysiological mechanisms of the disease. An improved classification based on such biological markers (i.e. of insulin resistance, beta cell dysfunction, autoimmunity) may assist in clinical decision and may offer the opportunity of an optimized therapeutic strategy. We address here some important questions that have not yet been clarified, e.g. which markers/indicators best define the main pathogenic mechanisms of the disease in a patient with diabetes and what threshold values are relevant for this purpose.
\end{abstract}

Keywords: diabetes mellitus, classification, biological markers, pathophysiologic mechanisms

\section{Rezumat}

Doctrina şi practica noastră clinică curentă este bazată pe o clasificare a diabetului care depinde mai degrabă de unele criterii/manifestări clinice decât de markeri ai mecanismelor patofiziologice ale bolii. O clasificare imbunătătită bazată pe astfel de markeri biologici (de exemplu, ai insulinorezistenţei, disfuncţiei beta celulare sau ai autoimunităţii) poate servi la luarea unor decizii clinice şi poate oferi oportunitatea unei strategii terapeutice optimizate. Luăm în discuţie aici câteva întrebări importante care încă nu au fost clarificate, de ex. care markeri/ indicatori definesc cel mai bine principalele mecanisme patogenetice ale bolii la un pacient cu diabet şi care sunt valorile lor prag relevante in acest scop.

Cuvinte cheie: diabet zaharat, clasificare, markeri biologici, mecanisme patofiziologice

Received: $21^{\text {st }}$ October 2015; Accepted: 15 th December 2015; Published: 24 ${ }^{\text {th }}$ December 2015

\footnotetext{
*Corresponding author: Simona Cernea, University of Medicine and Pharmacy Tîrgu Mures, Romania, e-mail: simona.cernea@rrml.ro
} 
It is generally accepted that diabetes mellitus is a complex and heterogeneous condition in terms of genetic background, pathophysiological mechanisms and clinical manifestations. The presentation at diagnosis varies largely, ranging from a totally asymptomatic patient with slightly increased blood glucose levels to a patient presenting in critical condition with severe hyperglycaemia and symptoms of acute metabolic decompensation. The initial presentation depends not only on the pathogenic mechanisms involved and the patient's genotype/phenotype, but also on the moment during the natural history of the disease when the diagnosis is made.

Several authors argue that diabetes is actually one disease extending continuously from autoimmune diabetes with onset at a very young age at one end of the spectrum to the age-related deterioration of glucose tolerance at the other end $(1,2)$. This theory is also supported by the "accelerator hypothesis" implying that diabetes is determined by the pancreatic beta cells loss, which occurs on different genetic backgrounds and at different rates, depending on the number, type and intensity of "accelerators": e.g. insulin resistance, glucotoxicity, autoimmunity or the intrinsic beta cell apoptosis $(3,4)$.

However, our current clinical doctrine is based upon a classification of type 1 diabetes (T1D) or type 2 diabetes (T2D), which relies on some clinical and laboratory traditionally-used criteria, such as age, body mass index (BMI), presence and severity of symptoms and / or ketosis, degree of hyperglycemia at diagnosis, perceived need for exogenous insulin relative to the time at diagnosis and diabetes-specific autoantibodies (where available) (1). Even if these criteria help discriminate most cases as having a typical T1D or T2D phenotype, the reality is that in clinical practice not all subjects can be easily classified as having one of the two types. This is partly due to the fact that none of the above-mentioned criteria is exclusively correlat- ed with either type and/or they do not have a precise threshold value that would allow an impeccable categorization (1). For example, age is just a guiding criterion, because T1D can also begin in adulthood and on the other hand the incidence of T2D diagnosed in adolescents and children has significantly increased during last years (1). Also, diabetes specific autoantibodies that have been traditionally associated with T1D have also been identified in subjects with T2D phenotype (5). Similarly, though ketoacidosis is a cardinal feature of T1D, it is not an absolute criterion, as there are cases without ketoacidosis at diagnosis (depending on how early during the course of the disease the patient is diagnosed) and in turn, some individuals with T2D may develop ketoacidosis (mainly if they are in advanced stages with more pronounced endogenous insulin deficiency) (6).

The current clinical algorithm/classification relies mainly upon clinical manifestations rather than the pathophysiological mechanisms of the disease, this being its possible failing. Another significant issue is that the two major types of diabetes are partially overlapping and are actually not as distinct as previously thought or, if we accept the aforementioned theory, we are, in fact, dealing with many facets of one single disease. Intermediate phenotypes of diabetes have been recognized, such as LADA (latent autoimmune diabetes of the adult) or the so-called "double diabetes" which share clinical and biological characteristics of both T1D and T2D and have an intermediate rate of disease progression (2). It has also been shown that up to a quarter of subjects with diabetes (mainly young people) may be misclassified by type, with possible therapeutic consequences (7-10). Rarer types of diabetes include MODY and other types of monogenic diabetes as well as diabetes secondary to pancreatic or other endocrine disturbances, which may also pose a significant diagnostic and therapeutic challenge. 
Therefore, we as others think that the current taxonomy of diabetes as T1D or T2D is somewhat simplistic and a more sophisticated classification is warranted (11-13). Different alternative schemes have been proposed, and a classification based on the main pathogenic mechanisms appears to be more appropriate, is of clinical relevance and may enable diabetes therapy from the start to be more targeted and efficient and go beyond simple glycemic control. A new classification scheme should also be simple, convenient and sufficient to categorize all subjects with diabetes. It should be based upon the use of biomarkers in a cost effective manner.

So the question remains as to which biological mechanisms and markers are adequate and sufficient to better define one's diabetes? As it is widely accepted that the core defect in diabetes is the loss of pancreatic beta cell function and mass, assessing the residual beta cell functional capacity for this purpose seems logical. Further- more, the role of insulin resistance and autoimmunity in significantly affecting disease progression has long been recognized. Besides their clinical relevance, it is of equal importance that for each of these pathogenic mechanisms there are potential biomarkers that would help define them and their contribution to the disease. Moreover, the therapeutical agents available for the treatment of diabetes differentially target insulin resistance and insulin deficiency, with some targeting both, thereby supporting the clinical implication of this classification.

\section{Suggested algorithm for an improved classification}

We suggest here a new classification of the disease based on a practical and simple algorithm that takes into account these features, that helps better define the phenotypes of diabetes and would assist in deciding the appropriate therapy for the patient (Figure 1).

\begin{tabular}{|c|c|c|}
\hline & DIAGNOSIS AND CLASSIFICATION ALGORITHM & METHODS OF ESTIMATION \\
\hline STEP I & DIAGNOSIS OF DIABETES & ADA criteria of diagnosis \\
\hline STEP 2 & Decreased & $\begin{array}{ll}\text { - } & \text { Fasting/stimulated/random } \mathrm{C}- \\
& \text { peptide? } \\
\text { - } & \text { HOMA- } \beta \text { ? } \\
\text { - } & \text { Urine c peptide/creatinine ratio? }\end{array}$ \\
\hline STEP 3 & Present & $\begin{array}{ll}- & \text { HOMA-IR ? } \\
- & \text { QUICKI ? } \\
- & \text { BMI ? } \\
- & \text { IS score ? }\end{array}$ \\
\hline (STEP 4) & Positive & $\begin{array}{ll}- & \text { Anti-GAD } \\
- & \text { Anti-IA-2 } \\
- & \text { Anti-ICA } \\
- & \text { Anti-Insulin } \\
- & \text { T cells? }\end{array}$ \\
\hline
\end{tabular}

Figure 1. Suggested algorithm for diagnosis and categorization of diabetes and potential methods of estimation 
The diagnosis of diabetes relies upon demonstration of hyperglycemia as defined by the American Diabetes Association (ADA) guidelines. Clinical awareness for the rarer secondary types of diabetes (i.e. pancreatic diabetes, endocrinopathies) and full history and physical exam may assist in ruling out at a high probability these forms of disease.

Once the diagnosis of diabetes is made, one needs to answer two main questions:

1. Does the patient retain sufficient beta cell function: yes/no? (in other words, to what extent is the beta cell function impaired?)

2. Does the patient have significant insulin resistance: yes/no?

Based on these questions, a patient can be appointed to one of the following categories (Figure 2):
Type A: Decreased beta cell function, non-significant insulin resistance

Type B: Lost beta cell function, non-significant insulin resistance

Type C: Decreased beta cell function, significant insulin resistance

Type D: Lost Beta cell function, significant insulin resistance.

Type A category basically comprises lean subjects with T2D, some LADA and perhaps some patients with T1D who are diagnosed very early during the course of the disease, when they still retain significant beta cell function (pre-symptomatic period). A true type B patient is the classic patient with T1D who has practically lost beta cell function yet has completely normal insulin sensitivity. In addition, type B category may also include some lean LADA pa-

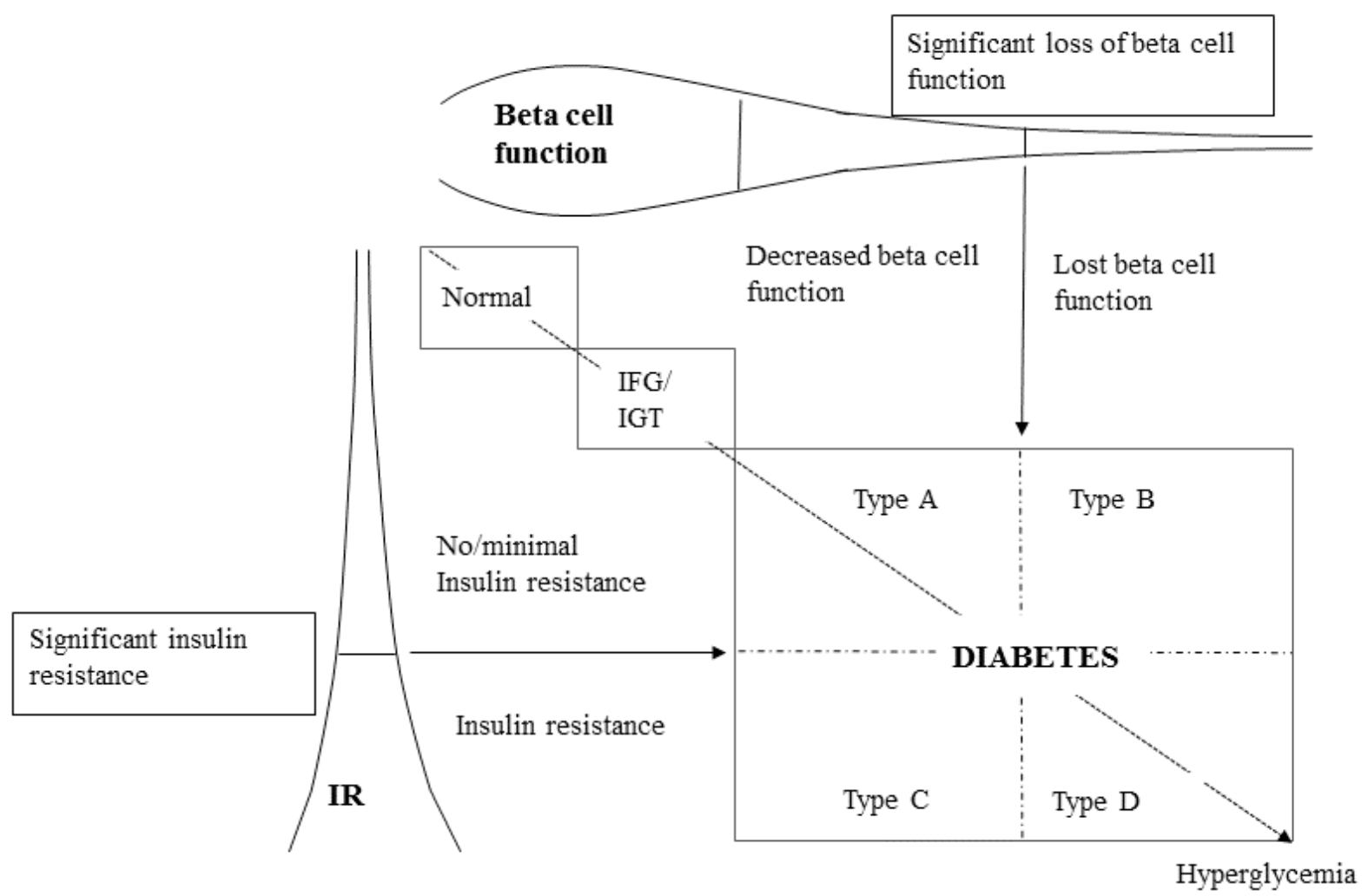

Figure 2. Categorization of diabetes according to the two main pathophysiological mechanisms 
tients who have lost beta cell function below a critical threshold and who have non-significant insulin resistance. Type $\mathrm{C}$ category includes the majority of patients with T2D at the earlier stages of disease and also perhaps some overweight or obese LADA subjects that present with clinically significant insulin resistance. Finally, type $\mathrm{D}$ category encompasses insulin resistant T2D subjects during the more advanced stages of the disease when they have lost beta cell function as well as T1D patients who are/have become overweight or obese and thus acquired significant insulin resistance.

We acknowledge the fact that the categories are not clear-cut, with a continuum extending between the different types. Certainly, during a lifetime, a patient can move from one category to another. For example, patients who are categorized as type A or B, may acquire insulin resistance by increasing weight, decreasing physical activity and/or perhaps by other mechanisms, and they can move to type C or D category, respectively. Also, in time, beta cell function decreases (due to multiple mechanisms, including autoimmunity, gluco-lipotoxicity, oxidative stress, endoplasmic reticulum stress, islet inflammation, islet amyloid, and aging), so patients who initially fit into type $\mathrm{A}$ or $\mathrm{C}$ categories, can later shift to type B or D category, respectively. Alternatively, a type $\mathrm{C}$ or $\mathrm{D}$ overweight/obese diabetic subject who initially presented with significant insulin resistance and loses weight by various means (diet and exercise or bariatric surgery) reverting insulin resistance, might theoretically move to type A or B category.

Of course, once this algorithm is accepted, we need to clarify a few remaining dilemmas. Perhaps, accessing large patients' databases from clinical trials with a longer duration of follow-up may help in finding relevant answers.

a. First, which tests should we use to measure beta cell function? Is measuring C-peptide levels appropriate and sufficient? There are available nowadays reliable and relatively non-expensive C-peptide assays that can be utilized for this purpose. However, it should be acknowledged that C-peptide is a surrogate marker of beta cell function and not indicative of beta cell mass and there are a number of limitations with its use (14). Should we measure fasting, random and/or stimulated C-peptide? Would a composite index of (stimulated) C-peptide and $\mathrm{HbA} 1 \mathrm{c}$ be more indicative for a significant beta cell loss? Or rather homeostasis model assessment (HOMA)- $\beta$, 2-h urine C-peptide/creatinine ratio or the disposition index should be used? The disposition index which evaluates endogenous insulin secretion adjusted for insulin resistance is used as a more precise measure of $\beta$-cell function (15). However, it implies performing an oral glucose tolerance test with several blood draws which is rather cumbersome for use in clinical practice. If any of these indices is to be employed on large scale, a stimulation test would not be adequate; rather indices based on fasting measurements should be routinely used.

The second obvious question is which cutoff values best discriminate subjects that retain clinically significant beta cell function? Is the DCCT value of 90-min stimulated C-peptide of $0.2 \mathrm{nmol} / 1$ relevant for all subjects? The cut-off values remains to be clearly defined, but so far some thresholds for fasting and stimulated/random C-peptide and urine C-peptide/creatinine ratio, respectively, that discriminate the absolute insulin deficiency/insulin requirement and various diabetes subtypes have been proposed (16). For instance, a stimulated C-peptide value of $0.2 \mathrm{nmol} / 1$ and a fasting C-peptide value of 0.08 $\mathrm{nmol} / 1$ have been suggested for detection of absolute insulin deficiency (16). Up to present the role of $\mathrm{C}$-peptide in determining the best timing for the initiation of insulin in a patient with classic T2D has not been clarified and usually it is the clinical course of the disease and not the laboratory results which lead this decision (17). Some 
studies seemed to indicate fasting and stimulated C-peptide levels of $0.3 \mathrm{nmol} / \mathrm{l}$ and 0.6-0.8 nmo$1 / 1$, respectively as cut-offs for successful insulin withdrawal, suggesting that these values distinguish insulin-requiring vs non-insulin requiring diabetes (18-20). However, it should be noted that the metabolic control in these studies was less stringent. Also, the C-peptide values, mainly the fasting ones, should be interpreted taken into consideration the presence of insulin resistance $(21,22)$.

b. Similarly, what is the best indicator of insulin resistance for routine clinical application? It is generally considered that insulin resistance is associated with obesity (mainly abdominal) and the degree of insulin resistance is proportionally related to fat mass and waist circumference. In clinical practice the BMI is generally used as a surrogate marker for insulin resistance, yet it is not a direct measure of insulin resistance, nor of fat mass. Additionally, individuals differ in the extent their fat mass affects the insulin sensitivity: the literature indicates that there are lean individuals with insulin resistance (metabolically unhealthy normal-weight) and conversely, obese individuals with high levels of insulin sensitivity (metabolically healthy obesity) (23-25). Since the reference method (i.e. hyperinsulinemic euglycemic clamp) or an alternative method (intravenous glucose tolerance test) are too burdensome to be routinely used in clinical practice, other simple indices, derived from fasting samples, such as HOMA-IR, quantitative insulin sensitivity check index (QUICKI) or insulin sensitivity score could be used instead (26). These have been assessed and validated against reference methods, but again there are several limitations with using simple indices, including decreased reliability in subjects with severe insulin deficiency $(26,27)$. In addition, the same problem remains with markers of insulin resistance: lack of cut-off levels that would discriminate clinically significant insulin resistance.
Some data in various patient populations suggest HOMA-IR values of 2.5 or 2.7 as indicators of insulin resistance $(28,29)$.

Theoretically, the thresholds for indices of beta cell dysfunction and of insulin resistance should identify subjects that would benefit from insulin replacement therapy and from therapies with an insulin-sensitizing effect, respectively. Certainly, these threshold values need validation in prospective randomized clinical studies.

When considering the complex pathophysiological mechanisms involved in diabetes, several other questions may arise. For example, the role of glucagon or the incretin hormones in the pathophysiology of diabetes are yet to be better defined. It is not clear at present if, for instance, defining the degree of hyperglucagonemia or the severity of incretin defect would add any benefit in terms of phenotyping or choice of therapy. Further research of the particular effects of drugs targeting the incretin system on the individual patient may yield additional pathophysiological distinctions in the diagnosis of diabetes - i.e. significant vs. insignificant incretin deficiency or resistance.

Since autoimmunity plays an important role in disease progression (in classical T1D and LADA), we might consider addressing one additional question when delineating diabetes diagnosis:

3. Does the patient have markers of autoimmunity: yes/no?

However, an exhaustive assessment of the contribution of autoimmunity to the pathogenesis of diabetes in an individual patient may be costly and include tests which are not routinely used in clinical practice. Therefore, several issues regarding this point need to be discussed.

Which autoimmunity tests are necessary and sufficient to be performed in order to identify all patients with autoimmune disease and concurrently have a reasonable cost/benefit ratio? Should we measure at diagnosis anti-GAD, 
anti-IA2, anti-ICA and anti-insulin antibodies in all subjects with newly diagnosed diabetes? In our opinion this approach is too costly and most probably would not add a reasonable benefit in practice. Should we have an antibody cluster for a certain age category (for example, anti-GAD, anti-insulin and anti-IA-2 in young subjects and anti-GAD and anti-ICA in older individuals)? Should we test other autoantibodies, such as the newer anti-ZnT8? Or would a stepwise approach (with 1-2 autoantibodies tested per time) be more reasonable in terms of costs and convenience?

A more practical alternative would be to check the autoimmunity status in a certain category of subjects with diabetes. For example, we would suggest testing it in all type B subjects (with significant loss of beta cell function and no insulin resistance) and perhaps in those within type A category (decreased beta cell function, without significant insulin resistance) as some of them might have markers of autoimmunity which may predict their rapid progression towards significant loss of beta cell function. Subjects categorized as type D (loss of beta cell function with a significant degree of insulin resistance) might also be considered for assessment of autoimmunity status, as this category might include patients with autoimmune disease that have acquired insulin resistance from diagnosis or later on in life.

It is debated that it might not be worthy to measure diabetes autoantibodies in adulthood at all, given the lower number of autoantibodies in adult age as compared to childhood (30). Also, identifying autoimmunity is a prerequisite in case immune modulation is desired, but so far there is no immune agent available for clinical intervention, so the question is if deciphering autoimmunity at this point is practical. It might be considered in individual cases as the presence of autoantibodies is associated with a faster rate of disease progression towards absolute insulin requirement and perhaps in individuals at high risk for diabetes (e.g. first-degree relatives), as the presence of multiple autoantibodies has high positive predictive value for autoimmune diabetes (31).

In addition, there is data indicating that subjects negative for autoantibodies might be positive for diabetes-specific T cells (5). By definition, autoimmune diabetes is a cell-mediated condition, so obviously, identifying pathogenic (autoreactive) T cells is crucial for distinguishing autoimmunity. However, which methods should be used? So far, several T-cell assays identify diabetes-specific CD4+ and CD8+ T cells (e.g. cellular immunoblotting, ELISPOT, MHC tetramers), with specificity and sensitivity roughly ranging from $60-90 \%(32,33)$. Although progress has been made during recent years, there is no standardized T-cell assay readily available for clinical use so far.

A recently published scientific statement of the JDRF, Endocrine Society and ADA proposes a staging classification system for classical T1D that would help development of therapies and clinical trials (34). Stage 1 includes subjects with beta cell autoimmunity (one/two diabetes-specific autoantibodies) with normoglycemia, stage 2 defines the presence of autoimmunity with dysglycemia/glucose intolerance, both being presymptomatic and stage 3 represents the onset of symptomatic disease (34). In fact this staging classification superimposes with the one we suggest: stage 1 is actually the Normal category, stage 2 is the IFG/IGT category and stage 3 is Diabetes (Figure 2).

\section{Therapeutic implications of the new clinical algorithm}

Having discussed the three issues to address at diagnosis (beta cell reserve, insulin resistance and perhaps autoimmunity) the clinical implications of employing these additional tests must be justified by showing improved clinical man- 
agement with their utilization. A possible benefit of an approach based on biological markers and the patient's clinical and metabolic phenotype is to assist physicians when choosing the best therapeutic agents that address the pathological mechanisms in each subject, in a more individualized manner.

For example, it is recognized that insulin therapy may not be sufficient in some patients with classical $\mathrm{T} 1 \mathrm{D}$, and other therapeutical agents might be needed as adjunctive therapy to insulin (35). Considering the use of additional therapies on top on insulin early in the course of therapy of the severely insulin deficient patient may lead to faster attainment of glycemic control without the often accompanying weight gain, for example. It should also be mentioned that often in daily practice LADA is treated as classical T2D, as frequently the autoimmune status is not evaluated in such patients. On the other hand, it has already been discussed that the therapeutical algorithm in T2D which recommends subsequent addition of drugs, once metformin fails in maintaining adequate metabolic control, is basically a "treat-to-failure" approach. At present there are multiple therapeutical classes and agents available for the treatment of diabetes, each with its specific mechanisms of action, and choosing the second, third or possibly fourth drug for a patient might pose some difficulties. A "pathophysiological" approach with an early combination therapy employing agents that simultaneously correct established pathogenic defects from the beginning in a "one size fits all" manner has been advocated (36). Our therapeutical strategy is somewhat different in the sense that we suggest tailoring therapy to the individual, according to the identified $\operatorname{defect}(\mathrm{s})$ that should be targeted by adequate drugs, though we are also supporters of combining therapies from start if indicated by the test results. In this respect, it is important to note the dynamic nature of the disease and possibly repeating tests of beta cell reserve or insulin sensitivity at a later stage, once glucotoxicity has largely absolved, or when a significant deterioration of metabolic control occurs, may assist in better fine-tuning of therapy, though, again, this needs to be evaluated in a cost-effectiveness perspective.

The details regarding various interventions will not be discussed here, but some brief points can be highlighted. In case of low residual beta cell function it would be reasonable to start insulin replacement therapy from the beginning, regardless of autoimmune status, along with other adjunct therapies, if needed. There are proofs regarding the beneficial effects of even a short course of insulin therapy on preservation of beta cell function (38-40). Intensive insulin therapy given early in the course of the disease in subjects with newly diagnosed T2D was shown to restore the acute insulin response, improve and maintain on midterm beta cell function, even after insulin withdrawal $(36,38)$. Currently, we start insulin therapy if we detect autoimmunity (T1D) or based on glycemic status. However, the presence of autoimmunity should be a reason for immune intervention (currently available only in the settings of clinical trials) and glycemic values should rather guide the insulin dosage and regimen. The logic dictates to start insulin replacement whenever one estimates that there is significant insulin deficiency (based on markers discussed above). It would also be reasonable to take into account the effect of various agents on beta cell function, as some of them have been shown to be protective, while others not $(41,42)$. The protective effects of some therapeutical agents, such as incretin-based therapies, thiazolidindiones (TZD) and insulin occur either through direct mechanisms (reduction of apoptosis, promotion of beta cell proliferation, improvement in proinsulin processing a.s.o.) or indirectly by the decrease of glucotoxicity and beta cell rest (42).

The current dogmatic treatment algorithm does not indicate metformin as an option for 
individuals with T1D and insulin resistance, although benefits of this drug in such cases have been demonstrated in some studies (43). Meta-analysis and systematic reviews of clinical studies indicated that therapy with metformin in patients with T1D is associated with a decrease of daily insulin dosage, body weight, blood lipids, and in some of them, with decrease of $\mathrm{HbAlc}$ (44-46). The new suggested diabetes categorization allows metformin use in these patients, if significant insulin resistance is present, regardless of the autoimmune status. Similarly, other agents, such as glucagon-like peptide (GLP)-1 receptor agonists or sodium glucose cotransporter (SGLT)-2 inhibitors, approved for use in T2D, seem to confer some advantages in patients with T1D (47). Particularly, GLP-1 receptor agonists have been associated with improved glucose control, decreased blood glucose variability and insulin dosage in these subjects $(48,49)$. The favorable effects in such setting are probably obtained through several mechanisms: suppression of glucagon secretion, modulation of beta cell responsiveness to glucose and of gastric emptying $(50,51)$. The benefits of drugs approved for T2D observed in patients with autoimmune diabetes further supports the idea of an individualized, pathophysiological therapeutic approach.

One might consider initiating both insulin and metformin in cases where both insulin resistance and significant insulin deficiency are present, titrating the doses by the glucose and $\mathrm{HbAlc}$ values.

If autoimmunity is present, an immune modulating agent should ideally be administered, once one is developed and clearly demonstrates safety and efficacy in terms of beta cell preservation. A large number of articles regarding various immune interventions in autoimmune diabetes (T1D and LADA) have been published, but at present there is no immunomodulatory agent available for clinical use. A few data seem to indicate though some positive results at least for subsets of patients (e.g. LADA or T1D with low/ moderate risk HLA genotype) $(52,53)$.

In conclusion, we suggest here a new approach for categorizing diabetes based on the main pathogenic features, which represents a different perspective, in the attempt to face the actual changing and challenging reality of diabetes care. We have also raised some important dilemmas which could be addressed in future research: which are the best markers/indicators of significant insulin resistance and of beta cell loss, respectively, that can be routinely used in clinical practice and what are their threshold values that would help providers distinguish significant insulin resistance and beta cell loss in a patient with diabetes. We think that better definition of a patient's characteristics may offer the opportunity of an optimized therapeutic strategy which may assist in clinical decision and could possibly alter the natural course of the disease.

\section{Acknowledgments:}

The authors would like to thank Professor Itamar Raz for his valuable comments and suggestions and Mrs Rebecca Sprung for editorial support.

\section{References}

1. Brooks-Worrell B, Palmer JP. Is diabetes mellitus a continuous spectrum? Clin Chem 2011; 57(2):158-61. DOI: $10.1373 /$ clinchem.2010.148270

2. Lin J, Zhou ZG, Wang JP, Zhang C, Huang G. From Type 1, through LADA, to type 2 diabetes: a continuous spectrum? Ann N Y Acad Sci 2008 Dec; 1150:99-102. DOI: 10.1196/annals.1447.036

3. Fourlanos S, Harrison LC, Colman PG. The accelerator hypothesis and increasing incidence of type 1 diabetes. Curr Opin Endocrinol Diabetes Obes 2008; 15(4):3215. DOI: 10.1097/MED.0b013e3283073a5a

4. Wilkin TJ. The accelerator hypothesis:a review of the evidence for insulin resistance as the basis for type I as well as type II diabetes. Int J Obes (Lond) 2009; 33(7):716-26. DOI: 10.1038/ijo.2009.97 
5. Brooks-Worrell B, Narla R, Palmer JP. Islet Autoimmunity in Phenotypic Type 2 Diabetes Patients. Diabetes Obes Metab 2013; 15:137-40. DOI: 10.1111/ dom. 12167

6. Welch BJ, Zib I. Case Study:Diabetic Ketoacidosis in Type 2 Diabetes:"Look Under the Sheets". Clinical Diabetes 2004; 22(4):198-200. DOI: $10.2337 /$ diaclin.22.4.198

7. de Lusignan S, Khunti K, Belsey J, Hattersley A, van Vlymen J, Gallagher H, et al. A method of identifying and correcting miscoding, misclassification and misdiagnosis in diabetes:a pilot and validation study of routinely collected data. Diabet Med 2010; 27(2):203-9. DOI: 10.1111/j.1464-5491.2009.02917.x

8. de Lusignan S, Sadek N, Mulnier H, Tahir A, Russell-Jones D, Khunti K. Miscoding, misclassification and misdiagnosis of diabetes in primary care. Diabet Med 2012; 29(2):181-9. DOI: 10.1111/j.14645491.2011.03419.x

9. Stone MA, Camosso-Stefinovic J, Wilkinson J, de Lusignan S, Hattersley AT, Khunti K. Incorrect and incomplete coding and classification of diabetes:a systematic review. Diabet Med 2010; 27(5):491-7. DOI: 10.1111/j.1464-5491.2009.02920.x

10. Tripathi A, Rizvi AA, Knight LM, Jerrell JM. Prevalence and impact of initial misclassification of pediatric type 1 diabetes mellitus. South Med J 2012; 105(10):513-7. DOI: 10.1097/SMJ.0b013e318268ca60

11. Maraschin Jde F. Classification of diabetes. Adv Exp Med Biol 2012; 771:12-19.

12. Leslie RD, Kolb H, Schloot NC, Buzzetti R, Mauricio D, De Leiva A, et al. Diabetes classification:grey zones, sound and smoke:Action LADA 1. Diabetes Metab Res Rev 2008; 24(10):511-9. DOI: 10.1002/dmrr.877

13. Sobngwi E, Gautier JF. Adult-onset idiopathic Type I or ketosis-prone Type II diabetes:evidence to revisit diabetes classification. Diabetologia 2002; 45(2):283-5. DOI: 10.1007/s00125-001-0739-8

14. Cernea S, Raz I, Herold KC, Hirshberg B, Roep BO, Schatz DA, et al; D-Cure Workshop. Challenges in developing endpoints for type 1 diabetes intervention studies. Diabetes Metab Res Rev 2009; 25(8):694-704. DOI: $10.1002 /$ dmrr.1002

15. Bergman RN, Ader M, Huecking K, Van Citters G. Accurate assessment of beta-cell function:the hyperbolic correction. Diabetes 2002; 51 Suppl 1:S212-20. DOI: 10.2337/diabetes.51.2007.S212
16. Jones AG, Hattersley AT. The clinical utility of C-peptide measurement in the care of patients with diabetes. Diabet Med 2013; 30(7):803-17. DOI: 10.1111/ dme. 12159

17. Home P, Riddle M, Cefalu WT, Bailey CJ, Bretzel RG, Del Prato $\mathrm{S}$, et al. Insulin therapy in people with type 2 diabetes:opportunities and challenges? Diabetes Care 2014; 37(6):1499-1508. DOI: 10.2337/dc13-2743

18. Hohberg C, Pfutzner A, Forst T, Lubben G, Karagiannis E, Borchert M, et al. Successful switch from insulin therapy to treatment with pioglitazone in type 2 diabetes patients with residual beta-cell function:results from the PioSwitch study. Diabetes Obes Metab 2009; 11(5):464-71. DOI: 10.1111/j.1463-1326.2008.00975.x

19. Lee A, Morley J. Classification of type 2 diabetes by clinical response to metformin-troglitazone combination and C-peptide criteria. Endocr Pract 1999; 5(6):305-13. DOI: 10.4158/EP.5.6.305

20. Araki H, Tanaka Y, Yoshida S, Morita Y, Kume S, Isshiki K, et al. Oral glucose-stimulated serum C-peptide predicts successful switching from insulin therapy to liraglutide monotherapy in Japanese patients with type 2 diabetes and renal impairment. J Diabetes Investig 2014; 5(4):435-41. DOI: 10.1111/jdi.12169

21. Patel N, Taveira TH, Choudhary G, Whitlatch H, Wu WC. Fasting Serum C-Peptide Levels Predict Cardiovascular and Overall Death in Nondiabetic Adults. J Am Heart Assoc 2012; 1(6):e003152. DOI: 10.1161/ JAHA. 112.003152

22. Cernea S, Huţanu A, Coroş L, Dobreanu M. Assessment of beta cell function in subjects with newly diagnosed type 2 diabetes. Rev Romana Med Lab 2013; 21(2):145-160. DOI: 10.2478/rrlm-2013-0011

23. Eckel N, Mühlenbruch K, Meidtner K, Boeing $\mathrm{H}$, Stefan N, Schulze MB. Characterization of metabolically unhealthy normal-weight individuals:Risk factors and their associations with type 2 diabetes. Metabolism 2015; 64(8):862-71. DOI: 10.1016/j.metabol.2015.03.009

24. Boonchaya-anant P, Apovian CM. Metabolically healthy obesity--does it exist? Curr Atheroscler Rep 2014; 16(10):441. DOI: 10.1007/s11883-014-0441-1

25. Bell JA, Kivimaki M, Hamer M. Metabolically healthy obesity and risk of incident type 2 diabetes:a meta-analysis of prospective cohort studies. Obes Rev 2014; 15(6):504-15. DOI: 10.1111/obr.12157

26. Borai A, Livingstone C, Kaddam I, Ferns G. Selection 
of the appropriate method for the assessment of insulin resistance. BMC Med Res Methodol 2011; 11:158. DOI: $10.1186 / 1471-2288-11-158$

27. Dabelea D, D’Agostino RB Jr, Mason CC, West N, Hamman RF, Mayer-Davis EJ, et al. Development, validation and use of an insulin sensitivity score in youths with diabetes:the SEARCH for Diabetes in Youth study. Diabetologia 2011; 54(1):78-86. DOI: 10.1007/s00125010-1911-9

28. Geloneze B, Vasques AC, Stabe CF, Pareja JC, Rosado LE, Queiroz EC, et al; BRAMS Investigators. HOMA1-IR and HOMA2-IR indexes in identifying insulin resistance and metabolic syndrome:Brazilian Metabolic Syndrome Study (BRAMS). Arq Bras Endocrinol Metabol 2009; 53(2):281-7. DOI: 10.1590/S000427302009000200020

29. Ziaee A, Esmailzadehha N, Oveisi S, Ghorbani A, Ghanei L. The threshold value of homeostasis model assessment for insulin resistance in Qazvin Metabolic Diseases Study (QMDS):assessment of metabolic syndrome. J Res Health Sci 2015; 15(2):94-100.

30. Bonifacio E. Predicting type 1 diabetes using biomarkers. Diabetes Care 2015; 38(6):989-96. DOI: 10.2337/ dc15-0101

31. Pihoker C, Gilliam LK, Hampe CS, Lernmark A. Autoantibodies in Diabetes. Diabetes 2005; 54 (Suppl 2):S52-S61 DOI: 10.2337/diabetes.54.supp1_2.S52

32. Tooley JE, Herold KC. Biomarkers in type 1 diabetes:application to the clinical trial setting. Curr Opin Endocrinol Diabetes Obes 2014(4); 21:287-92. DOI: 10.1097/MED.0000000000000076

33. Herold KC, Brooks-Worrell B, Palmer J, Dosch HM, Peakman M, Gottlieb P, Reijonen H, Arif S, Spain LM, Thompson C, Lachin JM, et al; Type 1 Diabetes TrialNet Research Group. Validity and reproducibility of measurement of islet autoreactivity by T-cell assays in subjects with early type 1 diabetes. Diabetes 2009; 58(11):2588-95. DOI: $10.2337 / \mathrm{db} 09-0249$

34. Insel RA, Dunne JL, Atkinson MA, Chiang JL, Dabelea D, Gottlieb PA, et al. Staging Presymptomatic Type 1 Diabetes:A Scientific Statement of JDRF, the Endocrine Society, and the American Diabetes Association. Diabetes Care. 2015; 38(10):1964-74. DOI: 10.2337/ dc15-1419

35. Ludvigsson J. The latest pharmacotherapy options for type 1 diabetes. Expert Opin Pharmacother 2014; 15(1):37-49. DOI: $10.1517 / 14656566.2014 .855197$
36. DeFronzo RA, Eldor R, Abdul-Ghani M. Pathophysiologic approach to therapy in patients with newly diagnosed type 2 diabetes. Diabetes Care 2013; 36 Suppl 2:S127-138. DOI: $10.2337 / \mathrm{dcS} 13-2011$

37. Weng J, Li Y, Xu W, Shi L, Zhang Q, Zhu D, et al. Effect of intensive insulin therapy on beta-cell function and glycaemic control in patients with newly diagnosed type 2 diabetes: a multicentre randomised parallel-group trial. Lancet 2008; 371(9626):1753-60. DOI: 10.1016/ S0140-6736(08)60762-X

38. Kobayashi T, Nakanishi K, Murase T, Kosaka K. Small doses of subcutaneous insulin as a strategy for preventing slowly progressive beta-cell failure in islet cell antibody-positive patients with clinical features of NIDDM. Diabetes 1996; 45(5):622-6. DOI: 10.2337/ diabetes.45.5.622 DOI: 10.2337/diab.45.5.622

39. Harrison LB, Adams-Huet B, Raskin P, Lingvay I. $\beta$-cell function preservation after 3.5 years of intensive diabetes therapy. Diabetes Care 2012; 35(7):1406-12. DOI: $10.2337 / \mathrm{dc} 11-2170$

40. Raz I, Mosenzon O. Early insulinization to prevent diabetes progression. Diabetes Care 2013; 36:S190-7. DOI: $10.2337 / \mathrm{dcS} 13-2014$

41. Maedler K, Carr RD, Bosco D, Zuellig RA, Berney T, Donath MY. Sulfonylurea induced beta-cell apoptosis in cultured human islets. J Clin Endocrinol Metab 2005; 90(1):501-6. DOI: 10.1210/jc.2004-0699

42. Wajchenberg BL. Beta-cell failure in diabetes and preservation by clinical treatment. Endocr Rev 2007; 28(2):187-218. DOI: 10.1210/10.1210/er.2006-0038

43. Moon RJ, Bascombe LA, Holt RI. The addition of metformin in type 1 diabetes improves insulin sensitivity, diabetic control, body composition and patient well-being. Diabetes Obes Metab 2007; 9(1):143-5. DOI: 10.1111/j.1463-1326.2006.00599.x

44. Liu C1, Wu D, Zheng X, Li P, Li L. Efficacy and safety of metformin for patients with type 1 diabetes mellitus:a meta-analysis. Diabetes Technol Ther 2015; 17(2):142-8. DOI: 10.1089/dia.2014.0190

45. Vella S, Buetow L, Royle P, Livingstone S, Colhoun HM, Petrie JR. The use of metformin in type 1 diabetes:a systematic review of efficacy. Diabetologia. 2010;53(5):809-20. DOI: 10.1007/s00125-009-1636-9

46. Abdelghaffar S, Attia AM. Metformin added to insulin therapy for type 1 diabetes mellitus in adolescents. Cochrane Database Syst Rev. 2009;(1):CD006691. DOI: 10.1002/14651858.cd006691.pub2 
47. Munir KM, Davis SN. The treatment of type 1 diabetes mellitus with agents approved for type 2 diabetes mellitus. Expert Opin Pharmacother. 2015; 16(15):2331-41. DOI: $10.1517 / 14656566.2015 .1084502$

48. Traina AN, Lull ME, Hui AC, Zahorian TM, Lyons-Patterson J. Once-weekly exenatide as adjunct treatment of type 1 diabetes mellitus in patients receiving continuous subcutaneous insulin infusion therapy. Can J Diabetes 2014; 38(4):269-72. DOI: 10.1016/j.jcjd.2013.10.006

49. Crisci I, Aragona M, Politi KS, Daniele G, Del Prato S. GLP-1 receptor agonists in type 1 diabetes:a proofof-concept approach. Acta Diabetol. 2015; 52(6):11291133. DOI: $10.1007 / \mathrm{s} 00592-015-0800-6$

50. Ghazi T1, Rink L, Sherr JL, Herold KC. Acute metabolic effects of exenatide in patients with type $1 \mathrm{di}-$ abetes with and without residual insulin to oral and intravenous glucose challenges. Diabetes Care 2014;
37(1):210-16. DOI: $10.2337 / \mathrm{dc} 13-1169$

51. Kielgast U1, Holst JJ, Madsbad S. Antidiabetic actions of endogenous and exogenous GLP-1 in type 1 diabetic patients with and without residual $\beta$-cell function. Diabetes 2011; 60(5):1599-1607. DOI: 10.2337/db10-1790

52. Agardh CD, Cilio CM, Lethagen A, Lynch K, Leslie RD, Palmér M, et al. Clinical evidence for the safety of GAD65 immunomodulation in adult-onset autoimmune diabetes. J Diabetes Complications 2005; 19(4):23846. DOI: 10.1016/j.jdiacomp.2004.12.003

53. Buzzetti R, Cernea S, Petrone A, Capizzi M, Spoletini M, Zampetti S, et al; DiaPep Trialists Group. C-peptide response and HLA genotypes in subjects with recent-onset type 1 diabetes after immunotherapy with DiaPep277:an exploratory study. Diabetes 2011; 60(11):3067-72. DOI: $10.2337 / \mathrm{db} 10-0560$ 